\title{
Öğretmenlerin Okuldan Ayrılma Niyetlerinin Bir Yordayıcısı Olarak Kolektif Yeterlik
}

\section{Collective Efficacy as a Predictor of Teachers' Intent to Leave School}

\author{
Selçuk Demir ${ }^{\text {a* }}$

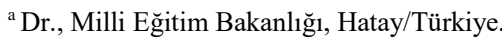 \\ ORCID: 0000-0003-2904-6443
}

\section{MAKALE BİLGİSI}

Makale Geçmişi:

Başvuru tarihi: 01 Şubat 2019

Düzeltme tarihi: 21 Mart 2019

Kabul tarihi: 01 Nisan 2019

\section{Anahtar Kelimeler:}

Kolektif öğretmen yeterliği

Okuldan ayrılma niyeti

Öğretmen
ÖZ

Kolektif yeterlik algısı, öğretmenlerin iş birliği ve dayanışma içerisinde başarılı olacaklarına inanmalarını sağlayan psikolojik bir etkide bulunmaktadır. Bu çalışmanın amacı kolektif yeterlik algısı ve alt boyutlarının, öğretmenlerin çalıştıkları okuldan ayrılma niyetleri ile ilişkisini ortaya koymaktır. Bu araştırmada ilişkisel tarama deseni kullanılmıştır. Araştırma verileri, 2018-2019 eğitim-öğretim yılında Hatay ilindeki devlet okullarında görevli $n=214$ öğretmenden toplanmıştır. Veriler, "Kişisel Bilgi Formu", "Kolektif Öğretmen Yeterliği Ölçeği”" ve "Okuldan Ayrılma Niyeti Ölçeği" aracılığıyla elde edilmiştir. Veri toplama araçları, araştırmacı tarafindan öğretmenlere dağıtılmış ve doldurulmuş formlar birkaç gün sonra araştırmacı tarafından alınmıştır. Regresyon analizi sonuçlarına göre kolektif öğretmen yeterliğinin öğretmenlerin okuldan ayrılma niyetini yordadığı bulunmuştur. Ayrıca kolektif öğretmen yeterliğinin alt boyutu olan öğretim stratejilerinin, okuldan ayrılma niyetini yordadığı ancak öğrenci disiplini alt boyutunun ise okuldan ayrılma niyetini yordamadığı tespit edilmiştir. Okul yöneticilerinin, öğretmenlerin bireysel üretkenliklerini arttırmalarından ziyade okul ortamında kolektif güç algısını oluşturmaları önerilmektedir.

\section{A B S T R A C T}

Collective efficacy perception has a psychological effect providing the teachers to believe they will be successful in cooperation and solidarity. The aim of this study is to reveal the relationships between collective teacher efficacy and its sub-dimensions and teachers' intent to leave school. In this research the relational screening model has been employed. The research data were gathered from $n=214$ teachers working at public schools in Hatay city in 2018-2019 academic year. Data were achieved by the means of "Teacher Information Form", "Collective Teacher Efficacy Scale" and "Intent to Leave School".Data collection tools were delivered to teachers and then filled forms were taken again by the researcher a few days later. In consequences of the regression analysis it has been found out that collective teacher efficacy predicts teachers' intent to leave school. Furthermore,the instructional strategies which is a sub-dimension of collective teacher efficiency predicts intent to leave school, whereas the student discipline sub-dimension does not predict. It's suggested that school administrators should constitute the perception of collective power rather than increase the reproductivity of teachers on an individual basis.

\section{Giriş}

Örgütler, çalışanların belli ortak amaçları gerçekleştirmek için bir araya geldikleri ortamlardır (Başaran, 1982). Çalışanların bu amaçları gerçekleştirmede birbirlerine destek olmaları, daha kaliteli çıktı ve hizmetlerin oluşmasını sağlamaktadır. Çağdaş yönetim yaklaşımlarında, takım ruhunun ve takım halinde çalışmanın örgüt başarısında önemli rol oynadığı bilinmektedir (DeRue, Hollenbeck, Ilgen ve Feltz, 2010; Tasa, Taggar ve Seijts,
2007). Çalışanların iş birliği yapması, dayanışma içinde olması ve takım ruhu oluşturması sadece kendilerini yetiştirmelerine değil; birbirlerinin bilgi, beceri ve kapasitelerini arttırmalarına da yardımcı olmaktadır. Örgüt çalışanlarının bireysel anlamda yetkin olmalarının ötesinde, örgütteki tüm çalışanların bütüncül bir yaklaşımla kolektif güç oluşturabilmelerinin sağlanması önem kazanan bir durumdur. Nitekim son yıllarda etkili yöneticilerin, güçlü ekipler ve takım ruhu oluşturabilme özellikleri ön plana çıkmaktadır (McEwan, 2018; Templar, 2011). Bireylerin,

*Sorumlu yazar/Corresponding author

e-posta: selcuk_demirs@hotmail.com 
diğer örgüt bireyleriyle ilişkilerinin ise iş yaşamlarını etkileyen önemli faktörlerden biri olduğu bilinmektedir (Özkalp ve Kırel, 2010; Şimşek, Çelik ve Akgemci, 2014).

Kolektif yeterlik, öz yeterlik kavramının grup düzeyine genişletilmesi ile ortaya çıkan (Kurt, 2012) anahtar bir performans değişkenidir. Luszczynska, Scholz ve Schwarzer (2005) öz yeterliğin; kişinin mücadele gerektirici bir işi başarabilme ve zorluklarla baş edebilme yeterliğine dair bireysel inancı olduğunu belirtmektedir. Diğer bir deyişle öz yeterlik, kişinin kendi yeterliğine olan inancıdır. Kolektif yeterliği Bandura (1997: 477), "belirli düzeylerde beceriler ortaya çıkarabilmek amacıyla gerekli eylem aşamalarını örgütleme ve yönetme yeteneklerine ilişkin grubun paylaşılmış inancı" şeklinde tanımlamıştır. Kolektif yeterlikte, öz yeterlikten farklı olarak grubun gücüne olan inanç söz konusu olmaktadır. Araştırmacılar (Fernandez Ballesteros, Diez-Nicolas, Carpara, Barbanelli ve Bandura, 2002) kolektif yeterliğin, bireysel yetkinliklere olan inançlar toplamından çok daha fazlası olduğunu ve grup seviyesinde bir tutum olduğunu ifade etmektedirler.

Öğretmenlerin sahip olduğu bütüncül yeterlik inanc1, öğretim kalitesini ve öğrenci başarısını etkilemektedir (Eells, 2011; Goddard, Hoy ve Woolfolk-Hoy, 2000; Tschannen-Moran ve Barr, 2004). Öğretmenlerin bulundukları grubun yeterli olduğuna inanmalarının ve gruplarıyla işbirliği içinde hareket etmelerinin, bireysel olarak da yeterliklerinin artmasını sağladığı görülmektedir. Araştırmacılar (Arıkan ve Çalışkan, 2013; Goddard ve Goddard, 2001; Kurt, 2012; Kurz ve Knight, 2004) çalışmalarında; kolektif yeterlik algısının, bireysel düzeydeki yeterlik algısıyla ilişkili olduğunu bulmuşlardır. Bireysel düzeyde yeterlik algısının ise örgütler tarafından istenen (Caprara, Barbaranelli, Steca ve Malone, 2006; Demir, 2018) ve istenmeyen öğretmen tutumları (Bolat, 2011; Skaalvik ve Skaalvik, 2010) ile ilişkili olduğu bilinmektedir.

İçinde bulundukları eğitim ortamı, öğretmenler üzerinde etkili olmakta ve onların davranışlarını bu doğrultuda şekillendirmektedir. Okulda belli amaçların sağlıklı bir şekilde gerçekleşmesi için öğretmenler ortak davranışlar sergilemektedir (Duman, Göçen ve Duran, 2013). Bu davranışlar, öğretmenler arası etkileşimi arttırmakta ve okulda bir bileşik güç algısı oluşturmaktadır. Bileşik güç algısı, öğretmenlere ortamlarındaki var olan dayanışma ile daha başarılı olacakları inancını yerleştirmektedir. Sahip olunan bu inanç, grubun daha çok gayret göstermesini ve kararlı olmasını sağlamaktadır. Bu konuda Schunk ve Pajares (2005: 86); “insanların kendileri hakkındaki algılarının, davranışlarının kestirilmesinde gerçek kapasitelerinden daha etkili olduğunu" ileri sürmektedir.

Çalışanların örgütlerinde fiziksel, zihinsel ve duygusal olumsuzluklar yaşaması işlerinde isteksizliğe yol açmaktadır (Yeni ve Özler, 2015). Bireylerin çalışma ortamları, yaşanılan olumsuzluklardan dolayı zamanla dayanılmaz bir hale gelmektedir. İşlerinde isteksiz ve ilgisiz çalışanlar, örgütlerinden ayrılmak istemektedirler. Robbins, Decenzo ve Coulter (2013); çalışanların ortama uyumu, geliştirilmesi ve eğitimi gibi konuların belli bir maliyet, emek ve zaman gerektirdiğini ifade etmektedirler. Ayrıca bir örgütün, çalışanların tekrar işlerine dönmelerini sağlamasıyla örgütten ayrılmaları neticesinde oluşacak durumların olumsuz etkilerinden kurtulacağını belirtmektedirler. Özkalp ve Kırel (2010); grup üyelerinin, belirledikleri amaçlara dayanışma içerisinde başarılı bir şekilde ulaştıklarında gruplarına bağlılıklarının arttığın ıileri sürmektedirler. $\mathrm{Bu}$ durumun grup üyelerinin, iş birliği yaparak daha üretken olacakları yönünde bir alg1 geliştirmelerinin bir sonucu olduğunu açıklamaktadırlar. Aynı ortamda ortak davranışlar sergilemelerinin kendilerini başarıya götürmesi, gruplarının gücüne olan inançlarını daha da pekiştirmektedir.

Eğitim örgütleri bağlamında düşünüldüğünde, öğretmenlerin sık sık okul değişikliğine başvurmalarının öğretim ortamına ve kalitesine zararlı etkileri olabilmektedir. Öğrencilerin başarısı, öğretmen değişikliğinden olumsuz etkilenebilmektedir. Tecrübeli ve mesleğinde yetkin bir öğretmenin okuldan ayrılmasıyla bir boşluk oluşmaktadır. $\mathrm{Bu}$ oluşan boşluk, başka bir öğretmenin örgüte katılmasıyla tamamlansa bile bu noktada da sorunlar çıkabilmektedir. Bu tür öğretmenlerin okuldan ayrılması hem mesai arkadaşları hem de öğrenciler açısından olumsuz etkiler bırakabilmektedir. Okuldaki birlik ve beraberlik ruhunun tekrar oluşturulması ise zaman almaktadır. Bursalığlu (2015); birlikte çalışan kişilerin sosyal bir grup oluşturduklarını ve benimsedikleri bu gruba bağlılık duygusu hissettiklerini ifade etmektedir. Bağlılık duygusunun ise okuldan ayrılma niyetini azalttığı bilinmektedir (Demir, 2019). Bursalığlu (2015) okul yöneticisinin, oluşturulan grubun başarısı ve sürekliliğini sağlamak olmak üzere iki temel görevinden söz etmektedir. Okul yöneticilerinin, öğretmenler arası etkileşimleri güçlendirmesi ve onları bütüncül bir yaklaşımla motive etmesi önemli görülmektedir.

Şimşek ve diğerleri (2014), örgüt üyelerinin yüksek derecede grup ruhu ve birlik duygusu içinde olmasının, her bir üyenin diğerlerinin durum ve davranışlarıyla da bütünsel anlamda ilgilenmesine katkı yaptığını açıklamaktadırlar. Ayrıca bu durumun, örgütte bütünleşmeyi sağladığı ve bütünleşmenin ise üyelerin örgütte kalmaya ilişkin motivasyonlarını arttırdığını ileri sürmektedirler. Hefferon ve Boniwell (2011); örgütteki tüm çalışanların yeterli ve yetenekli olduğuna inanan çalışanların, psikolojik olarak olumlu etkilendiğini ifade etmektedirler. Çalışanlar üzerindeki bu psikolojik etki, birlikte her türlü sorunun üstesinden gelebileceklerine ve her şeyi başarabileceklerine ikna olmalarını sağlamaktadır. Bu tür örgütlerde her bir çalışanın diğerleriyle birlikte yaptığı yatırımlar göz önüne alındığında, çalışanların örgütlerinden ayrılmaları zorlaşmaktadır (Kreitner ve Kinichi, 2009). Bu kapsamda Öcal ve Aydın (2009), grup üyelerinin grubun yeterliğine ilişkin algılarının; yapacakları tercihleri, harcayacakları çabanın miktarını ve başarısızlıklar karşısında grupta kalmaya devam edecekleri süreyi belirlediğini ileri sürmektedirler. İçinde bulundukları ortamın üyelerini yeterli ve başarılı gören, bu ortamda kendisinin de üretkenliğinin arttığını düşünen bireylerin, ortamda kalmaya devam edecekleri çıkarımında bulunulabilir.

Araştırmaların genel olarak öz yeterlik kavramı üzerine yoğunlaştığı, kolektif yeterliğe ilişkin çalışmaların sınırlı kaldığı, bu sınırlı çalışmaların da özellikle eğitim dışı örgütlerde yürütüldüğü görülmektedir. $\mathrm{Bu}$ araştırmaların kolektif yeterlik ile öz yeterlik ve performans gibi olumlu değişkenler arasındaki ilişkileri belirlemeye yoğunlaştığı dikkat çeken bir diğer konudur. Mevcut araştırmanın teorik 
ve pratik birçok yönden alana fayda sunması hedeflenmektedir. $\mathrm{Bu}$ araştırmada, üretkenlik ve performans1 etkileyen okuldan ayrılma niyetinin, kolektif yeterlik ve alt unsurları tarafından yordanıp yordanmadığ incelenmektedir. Kolektif yeterliğin olumsuz tutumlar üzerindeki rolünün incelenmesi ile özellikle yöneticilerin bu bileşik güç yapısının önemini daha iyi anlamaları sağlanacaktır. Bütüncül bir yaklaşımla öğretmenlerin olumsuz tutumlarının azaltılmasının önemi vurgulanmaktadır. Yöneticiler, kolektif güçten yararlanarak öğretmenlerin istenen ortak davranışlar geliştirmelerine katkı sunmaları hedeflenen bir diğer konudur. Mevcut araştırma; kolektif öğretmen yeterliği ve alt unsurlarının, öğretmenlerin çalıştıkları okuldan başka okula geçme niyetleri ile ilişkisini ortaya koymak amacıyla gerçekleştirilmiştir. Belirtilen bu temel amaç kapsamında araştırma soruları şu şekildedir:

1) Kolektif öğretmen yeterliği ile öğretmenlerin çalıştıkları okuldan başka bir okula geçme niyetleri arasında anlamlı bir ilişki var mıdır?

2) Öğretim stratejileri alt boyutu ile öğretmenlerin çalıştıkları okuldan başka bir okula geçme niyetleri arasında anlamlı bir ilişki var mıdır?

3) Öğrenci disiplini alt boyutu ile öğretmenlerin çalıştıkları okuldan başka bir okula geçme niyetleri arasında anlamlı bir ilişki var mıdır?

\section{Yöntem}

Araştırmanın bu kısmında; araştırmanın modeli, evren ve örneklemi, veri toplama araçları, verilerin toplanması ve analizi ile ilgili bilgiler verilmektedir.

\subsection{Araştırma Modeli}

$\mathrm{Bu}$ araştırmada, kolektif öğretmen yeterliği ve unsurlarının, okuldan ayrılma niyeti ile ilişkisi açıklanmaktadır. Dolayısıyla bu araştırmada iki ya da daha fazla değişken arasında ilişkinin varlığını ve düzeyini ortaya koyan ilişkisel tarama deseni (Balc1, 2016; Büyüköztürk, Çakmak, Akgün, Karadeniz ve Demirel, 2012; Karasar, 2012) kullanılmıştır.

\subsection{Evren ve Örneklem}

Çalışmanın evreni, 2018-2019 eğitim-öğretim yılında Hatay ilindeki devlet okullarında görev yapan öğretmenlerden oluşmaktadır. Bu araştırmada Hatay'daki devlet okullarında görevli 214 öğretmen basit tesadüfi örnekleme yöntemiyle rastgele seçilmiştir.

Katılımciların $\quad(n=214)$ \%53.7'sini erkek $(n=115)$ ve \%46.3'ü kadınlar (n=99) oluşturmaktadır. Araştırmaya katılan öğretmenlerin \%79.4'ü evli $(n=170)$ ve \%20.6's1 bekâr öğretmenlerdir $(n=44)$. Katılımcıların $(n=214)$ en fazla bulundukları $(\mathrm{n}=94)$ kıdem aralığı $\% 43.9$ ile $1-10$ yıl arası ve en az bulundukları $(n=30)$ kıdem aralığı ise \%14 ile 21 yıl ve üzeri olduğu görülmektedir.

\subsection{Veri Toplama Araçları}

Kişisel bilgi formunda; katılımcılardan cinsiyet, medeni durum ve kıdemlerine dair bilgi toplanmıştır. Beşli likert tipi iki farklı ölçeğin kullanıldığı bu araştırmada, ölçeklere ilişkin bilgiler aşağıda sunulmaktadır.

Kolektif öğretmen yeterliği ölçeği: $\mathrm{Bu}$ araştırmada; Tschannen-Moran ve Barr (2004) tarafindan geliştirilen, Erdoğan ve Dönmez (2015) tarafindan Türkçeye uyarlanan "Kolektif Öğretmen Yeterlik Ölçeği” kullanılmıştır. Ölçek, 12 maddeden ve iki boyuttan (öğretim stratejileri ve öğrenci disiplini) oluşmaktadır. Bu araştırmanın verileriyle geçerlik ve güvenirlik analizleri yapılmıştır. Bartlett Küresellik Testinin sonucunun anlamlı ve Kaiser-Meyer-Olkin (KMO) katsayısının .86 olduğu açığa çıkarılmıştır. Ölçek maddelerinin faktör yükleri .65 ile .88 arasında değiştiği bulunmuştur. Öğretim stratejileri boyutunun açıkladığı varyans yüzdesi 36.50, öğrenci disiplini boyutunun açıkladığ1 varyans yüzdesi 45.40 ve bu iki boyutun açıkladığı toplam varyans yüzdesinin 81.90 olduğu görülmüştür. Bu araştırmada, Cronbach's Alpha Güvenirlik Katsayıs1 öğretim stratejileri boyutu için .87, öğrenci disiplini boyutu için .90 ve ölçeğin tamamında .91 şeklinde hesaplanmıştır.

Çalıştığı okuldan ayrılma (başka bir okula geçme) niyeti ölçeği: Bu ölçek; Karakuş, Toprak ve Gürpınar (2014) tarafından geliştirilmiş olup tek boyut ve 4 maddeden oluşmaktadır. $\mathrm{Bu}$ araştırma kapsamında, geçerlik ve güvenirlik analizleri yapılmıştır. Bartlett Küresellik Testi sonucunun anlamlı ve Kaiser-Meyer-Olkin (KMO) katsayısının .83 olduğu görülmüştür. Ölçekteki maddelerin faktör yükleri değerlerinin .94 ile .96 arasında değiştiği tespit edilmiştir. Ölçme aracının açıkladığı toplam varyansın \%90.32 ile orijinal formunda olduğu gibi tek faktörle açıklandığı bulunmuştur. Bu araştırmada, ölçeğin Cronbach's Alpha Güvenirlik Katsayısı ise .96 olarak hesaplanmıştır.

\subsection{Verilerin Toplanmas1}

Kişisel bilgi formu ile kolektif öğretmen yeterliği ve çalıştığı okuldan ayrılma niyeti ölçeklerinin bulunduğu formlar, öğretmenlere dağıtılmıştır. Öğretmenlere bu kavramlarla ilgili kısa bir bilgi verilmiş, araştırmanın amacı belirtilmiş ve kendi algılarına en uygun seçeneği işaretlemelerinin beklendiği açıklanmıştır. Araştırmaya, öğretmenlerin gönüllü katılımları sağlanmıştır.Araştırmaya katılmayı kabul eden öğretmenlere, araştırmacı tarafindan kişisel bilgi formu ve ölçeklerin bulunduğu formlar verildikten birkaç gün sonra bu formlar tekrar araştırmacı tarafindan geri alınmıştır.

\subsection{Verilerin Analizi}

Öğretmenlerin kolektif yeterlikleri ve okuldan ayrılma niyetlerine ilişkin algıları arasındaki ilişki korelasyon analizi ile incelenmiş. Anlamlı ilişkilerin tespit edilmesinin ardından kolektif yeterlik ve alt unsurlarının okuldan ayrılma niyetini yordayıp yordamadığı ortaya çıkarılmıştır. Dolayısıyla son olarak basit ve çoklu regresyon analizleri gerçekleştirilmiştir. Basit regresyonda kolektif yeterlik, çoklu regresyonda ise kolektif yeterliğin alt boyutları bağımsız değişken olarak alınmıştır. Basit ve çoklu regresyonun her ikisinde de okuldan ayrılma niyeti bağımlı değişken olarak analiz edilmiştir. 


\section{Bulgular ve Yorumlar}

Bu bölümde betimsel analizler, korelasyon matrisi, basit ve çoklu regresyon analizleri ile ilgili bulgular yer almaktadır.

\subsection{Değişkenlerle İlgili Betimsel Analizler ve Korelasyon Matrisi}

$\mathrm{Bu}$ araştırma kapsamında aritmetik ortalama, standart sapma ve standart hata değerleri ile korelasyon değerleri Tablo 1'de sunulmaktadir.

Tablo 1. Kolektif öğretmen yeterliği ve alt boyutları ile okuldan ayrılma niyeti değişkenlerine ilişkin değerler

\begin{tabular}{lccccccc}
\hline Değişkenler & $\overline{\mathrm{X}}$ & SS & $\begin{array}{c}\text { Std. } \\
\text { Hata }\end{array}$ & 1 & 2 & 3 & 4 \\
\hline 1. Yeterlik & 3.94 & .67 & .04 & 1 & & & \\
2. Strateji & 3.95 & .73 & .05 & $.86^{* *}$ & 1 & & \\
3. Disiplin & 3.93 & .71 & .04 & $.96^{* *}$ & $.71^{* *}$ & 1 & \\
4. Ayr1lma & 2.42 & 1.33 & .09 & $-.21^{* *}$ & $-.21^{* *}$ & $-.19^{* *}$ & 1 \\
\hline * $<<.05, * * \mathrm{p}<.01$ & & & & & &
\end{tabular}

Notlar: Yeterlik: Kolektif yeterlik, Strateji: Öğretim stratejileri, Disiplin: Öğrenci disiplini, Ayrılma: Çalıştı̆̆ Okuldan Ayrılma Niyeti

Tablo 1 incelendiğinde; öğretmenlerin, kolektif öğretmen yeterliği ve alt boyutlarına ilişkin algıları kısmen yüksek düzeydeyken çalıştıları okuldan başka bir okula geçme niyetlerine ilişkin algıları kısmen düşük düzeydedir. Korelasyon değerleri gözden geçirildiğinde ise kolektif öğretmen yeterliği ve alt boyutlarının, çalıştığı okuldan ayrılma niyeti ile negatif, anlamlı ve düşük düzeyde ilişkili olduğu görülmektedir. Araştırmacı, elde edilen bulgulara ilişkin daha güçlü kanıtlar sunmak üzere basit ve çoklu regresyon analizleri yürütmüştür. $\mathrm{Bu}$ sayede kolektif yeterliğin ve alt boyutlarının, okuldan ayrılma niyetinin anlamlı bir yordayıcısı olup olmadığını ve yordayıcılarsa yordama güçlerinin açığa çıkarılması hedeflenmiştir.

\subsection{Kolektif Yeterliğin Öğretmenlerin Çalıştıkları Okuldan Ayrilma Niyetlerini Yordamas1}

Kolektif öğretmen yeterliğinin öğretmenlerin çalıştıkları okuldan başka bir okula geçme niyetlerini yordamasına ilişkin regresyon analizi sonuçları Tablo 2'de sunulmaktadır.
Tablo 2.Kolektif yeterliğin çalışılan okuldan ayrılma niyetin yordamasına ilişkin regresyon analizi sonuçları

\begin{tabular}{|c|c|c|c|c|c|c|}
\hline Model & $\begin{array}{l}\text { Yordayıcı } \\
\text { değişkenler }\end{array}$ & B & $\begin{array}{l}\text { Std. } \\
\text { Hata }\end{array}$ & Beta & $\mathrm{t}$ & $\mathrm{p}$ \\
\hline \multirow{4}{*}{ 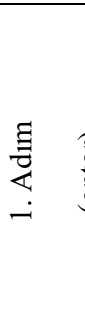 } & (sabit) & 2.745 & .834 & & 3.290 & .001 \\
\hline & $\begin{array}{l}\text { Cinsiyet } \\
\text { (dummy) }\end{array}$ & -.032 & .190 & -.012 & -.168 & .867 \\
\hline & yas & -.004 & .035 & -.023 & -.108 & .914 \\
\hline & k1dem & -.013 & .035 & -.079 & -.370 & .712 \\
\hline \multirow{5}{*}{$\begin{array}{l}\Xi \\
\vdots \\
⿱ 亠 䒑 \\
ن\end{array}$} & (sabit) & 4.290 & .959 & & 4.474 & .000 \\
\hline & $\begin{array}{l}\text { Cinsiyet } \\
\text { (dummy) }\end{array}$ & -.048 & .186 & -.018 & -.257 & .798 \\
\hline & yas & -.002 & .034 & -.009 & -.044 & .965 \\
\hline & k1dem & -.013 & .035 & -.078 & -.372 & .710 \\
\hline & $\begin{array}{l}\text { kolektif } \\
\text { yeterlik }\end{array}$ & -.411 & .133 & -.208 & -3.088 & .002 \\
\hline
\end{tabular}

Bağımlı değişken Çalıştı̆̆ı okuldan ayrılma niyeti

$\mathrm{R}^{2}$ değişim $=.043 * \mathrm{p}<.05, * * \mathrm{p}<.01$

Tablo 2'deki kısmi regresyon analizinde, demografik değişkenlerin (cinsiyet, yaş ve kıdem) 1.adımda kontrol edilmesiyle 2. adımda kolektif öğretmen yeterliğinin, öğretmenin çalıştığı okuldan ayrılma niyetini negatif ve anlamlı olarak yordadığı görülmektedir $\left(\beta=-.208^{* *}\right.$, $\mathrm{p}<0.01)$. Diğer bir deyişle öğretmenlerin; kolektif öğretmen yeterliği algısındaki her 1 birimlik artış, .208 birimlik okuldan ayrılma niyeti azalışına katkı sunmaktadır. Kolektif öğretmen yeterliği, öğretmenin çalıştı̆ı okuldan ayrılma niyetindeki varyansın \%4.3' ünü açıklamaktadır $\left(\Delta \mathrm{R}^{2}=.043\right.$; $\mathrm{p}<0.01)$. Öğretmenlerin kolektif yeterliklerine olan inançlarının artmasının, düşük düzeyde de olsa çalıştıkları okuldan başka bir okula geçme niyetlerini azalttı̆̆ 1 görülmüştür.

3.3. Kolektif Yeterliğin Alt Boyutlarının Öğretmenin Çalıştığı Okuldan Ayrılma Niyetini Yordaması

Kolektif öğretmen yeterliğinin alt boyutlarının öğretmenin çalıştığı okuldan ayrılma niyetini yordamasına ilişkin çoklu regresyon analizi (stepwise yöntemi) sonuçları Tablo 3'te görülmektedir. 
Tablo 3. Kolektif yeterliğin öğretim stratejileri alt boyutunun öğretmenlerin çalıştığı okuldan ayrılma niyetini yordamasına ilişkin çoklu regresyon analizi sonuçları

\begin{tabular}{|c|c|c|c|c|c|c|c|}
\hline \multicolumn{2}{|c|}{ Model } & $\begin{array}{c}\text { Yordayıcı } \\
\text { değişkenler }\end{array}$ & B & $\begin{array}{l}\text { Std. } \\
\text { Hata }\end{array}$ & Beta & $\mathrm{t}$ & $\mathrm{p}$ \\
\hline \multirow{4}{*}{ 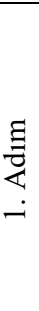 } & \multirow{4}{*}{$\begin{array}{l}\text { ब्ञ } \\
\text { है }\end{array}$} & (sabit) & 2.745 & .834 & & 3.290 & .001 \\
\hline & & $\begin{array}{l}\text { Cinsiyet } \\
\text { (dummy) }\end{array}$ & -.032 & .190 & -.012 & -.168 & .867 \\
\hline & & yas & -.004 & .035 & -.023 & -.108 & .914 \\
\hline & & k1dem & -.013 & .035 & -.079 & -.370 & .712 \\
\hline \multirow{5}{*}{ 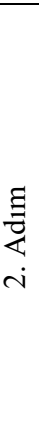 } & \multirow{5}{*}{ 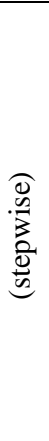 } & (sabit) & 4.200 & .945 & & 4.445 & .000 \\
\hline & & $\begin{array}{l}\text { Cinsiyet } \\
\text { (dummy) }\end{array}$ & -.076 & .187 & -.028 & -.406 & .685 \\
\hline & & yas & -.003 & .034 & -.020 & -.094 & .925 \\
\hline & & k1dem & -.011 & .035 & -.065 & -.311 & .756 \\
\hline & & $\begin{array}{l}\text { Öğretim } \\
\text { stratejileri }\end{array}$ & -.374 & .122 & -.208 & -3.076 & .002 \\
\hline
\end{tabular}

Bağımlı değişken çalıştığı okuldan ayrılma niyeti

$\mathrm{R}^{2}$ değişim $=.043 * \mathrm{p}<.05, * * \mathrm{p}<.01$

Tablo 3'teki çoklu regresyon analizine bakıldığında ise demografik değişkenler 1.adımda kontrol edilmiş ve 2 . adımda (stepwise ile) kolektif öğretmen yeterliğinin öğretim stratejileri ve ögrenci disiplini alt boyutları modele eklenmiştir. Kolektif öğretmen yeterliğinin öğretim stratejileri alt boyutunun çalıştığı okuldan ayrılma niyetini negatif ve anlamlı olarak yordadığı tespit edilmiștir $(\beta=$ $\left..208^{* *}, \mathrm{p}<0.01\right)$. Öğrenci disiplini alt boyutunun ise çalıştığı okuldan ayrılma niyetinin bir yordayıcısı olmadığ ve bu yüzden çoklu regresyon analizinden (stepwise yöntemi) çıkarıldığı görülmektedir. Öğretmenlerin öğretim stratejilerine yönelik algılarındaki her 1 birimlik artış, .208 birimlik çalıştığı okuldan ayrılma niyeti azalışını sağlamaktadır. Öğretim stratejileri unsuru, çalıștığı okuldan ayrılma niyetindeki toplam varyansın \%4.3'ünü açıklamaktadır $\left(\Delta \mathrm{R}^{2}=.043 ; \mathrm{p}<0.01\right)$. Öğretmenlerin öğretim stratejilerine iliş̧kin yeterlik algılarının artması, başka bir okula geçme niyetlerini düşük düzeyde de olsa azalttığ görülmektedir.

\section{Tartışma, Sonuç ve Öneriler}

$\mathrm{Bu}$ araştırmada yapılan korelasyon analizinde değişkenlerin birbirleriyle anlamlı ilişkilere sahip olduğu bulunmuştur. Kısmi regresyon analizinde, öğretmenlerin kolektif yeterlik algılarının çalıştıkları okuldan başka bir okula geçme niyetlerini azalttığ analizinde ise kolektif öğretmen yeterliğinin, öğretim stratejileri alt boyutunun, öğretmenlerin okuldan ayrılma niyetlerini azalttığı; öğrenci disiplini alt boyutunun ise okuldan ayrılma niyeti üzerinde anlamlı bir etkisinin olmadığı ortaya çıkarılmıştır.

Özkalp ve Kırel (2010) üyelerin, hedeflere işbirliği ve dayanışma içerisinde ulaşmalarının, gruplarına bağlılıklarını arttırdığını ileri sürmektedir. $\mathrm{Bu}$ durumun nedeninin, grup üyelerinin birlikte olmakla daha başarılı ve yeterli sonuçlar alabileceklerine inanç duymaları olduğunu belirtmektedirler. Bu kapsamda Şimşek ve diğerleri (2014) grup ruhu ve birlik duygusunun, her bir çalışanın diğerlerinin durum ve davranışlarıyla da ilgilenmesini ve bu durumun da örgütte çalışanların bütünleşmesini sağladığını ifade etmektedirler. Öcal ve Aydın (2009) ise bireylerin grubun yeterliğine ilişkin algılarının; tercihlerini, çaba miktarını ve gruptaki kalacakları süreyi etkilediğini açıklamaktadırlar. Grup üyelerinin, bir arada başarılı sonuçlar alacaklarına inanç duymalarının, grupta kalma isteklerini arttırdığı görülmektedir. $\mathrm{Bu}$ araştırmada da kolektif bir güç oluşturduklarında, bu şekilde daha yeterli ve başarılı sonuçlar alacaklarına inanan öğretmenlerin, örgütten ayrılma niyetlerinin azaldığı tespit edilmiştir.

Özdemir (2013) öğretmenlerin bireysel olarak mesleki gelişimlerinin, öğrencilerin öğrenmesini etkilemede tek başına yeterli olmadığını; okulun kolektif insan kapasitesinin geliştirilmesinin öğrenci öğrenmesini pozitif olarak etkilediğini belirtmektedir. Bazı araștırmacılar (Arıkan ve Çalışkan, 2013; Goddard ve Goddard, 2001; Kurt, 2012; Kurz ve Knight, 2004) çalışmalarında; kolektif yeterlik inancının, bireysel düzeydeki yeterlikle ilişkisini keşfetmişlerdir. Öğretim stratejileri konusunda öğretmenler, derslerde uygulanacak yöntemler hakkında birbirlerinden birçok şey öğrenirler ve öğrenci seviyelerine uygun olan bir yöntem izlerler. $\mathrm{Bu}$ sayede öğrencilerinin derinlemesine öğrenmelerine, eleştirel ve yaratıcı düşünmelerine katkı sunarlar. Öğrencilerinin başarılı bir öğrenme hayatı olduğunu gören öğretmenler, daha fazla emek sarf ederler. Dayanışma içerisinde birbirlerinin öğretme yeteneğini güçlendiren bu öğretmenlerin, beraberce oluşturdukları bu ortamdan ayrılmaları zorlaşır. Araştırmacılar (Eells, 2011; Goddard vd., 2000; Tschannen-Moran ve Barr, 2004); kolektif öğretmen yeterliğinin, öğretimin niteliğini ve öğrenci başarısını olumlu etkilediğini bulmuşlardır. $\mathrm{Bu}$ araştırma; öğretim stratejileri konusunda yetenekli öğretmenlerin, okullarından ayrılma niyetlerinin azaldığını göstermektedir. Diğer bir deyişle öğretmenlerin çalıştıkları ortamlarda iyi öğretim yapacaklarını düşünmeleri ve başaracaklarına inanmaları, okullarından ayrılma niyetlerini azaltmaktadır.

Mevcut araştırmada, kolektif öğretmen yeterliğinin öğrenci disiplini alt boyutunun öğretmenlerin okulda ayrılma niyetlerini yordamadığı görülmektedir. Bunun nedeni öğrencilerin sınıf kurallarına uymaları, beklenen davranışları sergilemeleri ve istenmeyen davranışlarının kontrol edilebilmesi gibi öğrenci disiplinini ilgilendiren konularda öğretmenlerin sınıflarında bireysel olarak başa çıkmaya gayret etmeleri olabilir. $\mathrm{Bu}$ durumun başka bir nedeni, her öğretmenin kendi sınıflarında, sınıf hakimiyetlerini kurmak istemeleri olabileceği belirtilebilir. $\mathrm{Bu}$ şekilde öğretmen, her öğrencisiyle özel ilgilenebilir ve farklı etkileşimler kurabilir. Evertson ve Emmer (2013) öğrencilerin sorunlu davranışlarında, öğretmenlerin öğrencilere doğru davranışı bulmalarına yardımcı ve sınıftaki olumlu iklimi korumaya olanak tanıyan uygun müdahalelerde bulunmalarının gerektiğini; okul idaresine yönlendirmenin ise durum kontrolden çıktığında ya da çok ciddi bir şekilde büyüdüğünde mümkün olabileceğini belirtmektedirler. Yeterlik algısına sahip öğretmenlerin, uygun yöntemlerin kullanımıyla etkili birer sınıf yöneticisi oldukları dolayısıyla ögrencilerin istenmeyen ve sorunlu 
davranışlarını düzeltmek için bireysel düzeyde çözümler bulabilecekleri düşünülmektedir.

Tecrübeli ve yetenekli öğretmenlerin, okullarından ayrılma niyetlerinin zararlı etkilerini en aza indirmek için özellikle okul yöneticisine belli sorumluluklar doğal olarak yüklenmektedir. Okul yöneticileri, öğretmen devrinin önüne geçebilecek çözümler üretebilmelidir. Bunun da en etkili yollarından birinin psikolojik mekanizmaları harekete geçirebilmek olduğu düşünülmektedir. Zira kolektif yeterlik alg1sı, okuldaki tüm öğretmenlerin iş birliği ve dayanışma içerisinde başarılı olacaklarına inanç duymalarını sağlayan psikolojik bir etkide bulunmaktadır.

Okul yöneticisi, okulunda iş birliğine dayalı kolektif bir güç algısı oluşturabilmelidir. Oluşturulacak olan kolektif güç, öğretmenler üzerinde bireysel bazda değil bütüncül bir yaklaşımla etkide bulunabilmelidir. Bunun sonucunda, öğretmenler, gerçek kapasitelerinden daha etkili olurlar. Öğretmenler, öğretim stratejileri ve öğrenci disiplini konularında birbirlerinden birçok şey öğrenme firsatı elde ederler. Bunların yanı sıra okulda oluşacak bir sorunda ya da başarısızlıkta öğretmenlerin kenetlenmeleri ve beraberce soruna çözüm aramaları sağlanabilir. Bu durumların doğal sonucu olarak, öğretmenlerin bir arada aynı okulda çalışmalarına ilişkin nedenler arttırılmış olur.

$\mathrm{Bu}$ araştırmada; kolektif güç algısı ve alt boyutlarının, olumsuz bir çalışan çıktısı üzerindeki rolü incelenmiştir. İleriki çalışmalarda, kolektif yeterliğin eğitim örgütlerinde üretim ve verimliliği etkileyen bireysel ve örgütsel olumlu çalışan çıktıları ile ilişkisinin incelenmesi gerekli görülmektedir. Kolektif güç algısının, örgüt ve insan kaynağı üzerindeki etkileri ortaya konulmalıdır. Yöneticilere; örgütteki üyelerin bir arada, işbirliği ve dayanışma içerisinde çalışabilmelerinin yolunu açan uygulanabilir model önerileri geliştirilebilir. $\mathrm{Bu}$ sayede bireylerin, gerçek kapasitelerinin üzerinde çalışmaları sağlanabilir.

\section{Kaynakça}

Arıkan, S. ve Çalışkan, S.C. (2013). Kolektif yeterlik üzerine yeni bağımsız değişken arayışları: Lider-üye etkileşiminin kolektif yeterlik üzerindeki etkisi üzerine bir araştırma. Türk Psikoloji Dergisi, 28 (71), 1-16

Balc1, A. (2016). Sosyal bilimlerde araştırma: Yöntem, teknik ve ilkeler. Ankara: Pegem Akademi.

Bandura, A. (2002). Social cognitive theory in cultural context. Journal of Applied Psychology: An International Review, 51, 269-290.

Bandura, A. (1997). Self-efficacy: The exercise of control. New York: W. H. Freeman and Company.

Başaran, İ. E. (1982). Örgütsel davranış. Ankara: Ankara Üniversitesi Eğitim Fakültesi Yayınları.

Bolat, O. İ. (2011). Öz yeterlik ve tükenmişlik ilişkisi: Lider-üye etkileşiminin aracılık etkisi. Ege Akademik Bakış, 11(2), 255-266.

Bursalığlu, Z. (2015). Okul yönetiminde yeni yapı ve davranış. Ankara: Pegem Akademi.
Büyüköztürk, Ş., Çakmak, E. K., Akgün, Ö. E., Karadeniz, Ş. V. ve Demirel, F. (2012). Bilimsel araştırma yöntemleri. Ankara: Pegem Akademi Yayıncılık.

Caprara, G.V., Barbaranelli, C., Steca, P.ve Malone, P.S. (2006). Teachers' self-efficacy beliefs as determinants of job satisfaction and students' academic achievement: A study at the school level. Journal of School Psychology, 44, 473-490.

Demir, S. (2018). Öz yeterliğin iş doyumu, örgütsel bağlılık, motivasyon ve işe sargınlıktaki rolü. Vrd International Eurasian Educational Research Congress, Antalya.

Demir, S. (2019). Etik iklim ve okuldan ayrılma niyeti arasındaki ilişki: Örgütsel bağlılığın aracılık rolü. Hacettepe Üniversitesi Eğitim Fakültesi Dergisi, 34(3), 824-838. doi: 10.16986/HUJE.2018040551

DeRue, D. S., Hollenbeck, J., Ilgen, D. ve Feltz, D. (2010). Efficacy dispersion in teams: Moving beyond aggrement and aggregation. Personnel Psychology, 63, $1-40$.

Duman, B., Göçen, G. ve Duran, V. (2013). İlköğretim öğretmenlerinin kolektif yeterlik düzeylerinin çeşitli değişkenler açısından incelenmesi. Hacettepe Üniversitesi Eğitim Fakültesi Dergisi, Özel sayı (1), 144-155.

Eells, R. J. (2011). Meta-analysis of the relationship between collective teacher efficacy and student achivement. Unpublished doctoral thesis. Chicago: Loyola University.

Erdoğan, U. ve Dönmez, B. (2015). Kolektif öğretmen yeterliği ölçeğinin Türkçeye uyarlanması: Geçerlik ve güvenirlik çalışması. Kuram ve Uygulamada Ĕ̆itim Yönetimi, 21(3), 345-366. doi: 10.14527/kuey.2015.013.

Evertson, C.M.ve Emmer, E.T. (2013). Ilkokul öğretmenleri için sınıf yönetimi. A. Aypay(çev. ed.). Ankara: Nobel Akademik Yayıncılık.

Fernandez-Ballesteros, R., Diez-Nicolas J., Carpara G. V., Barbanelli, C. ve Bandura, A. (2002). Determinants and structural relation of personal efficacy to collective efficacy. Applied Psychology: An International Review, 53(1), 107-125.

Goddard, R. D. ve Goddard, Y. L. (2001). A multilevel analysis of the relationship between teacher and collective efficacy in urban schools. Teaching and Teacher Education, 17(7), 807-818.

Goddard, R. D., Hoy, W. K. ve Woolfolk-Hoy, A. (2004). Collective efficacy: Theoretical development, empirical evidence, and future directions. Educational Researcher, 33(3) 3-13.

Goddard, R. D., Hoy, W.K. ve Woolfolk-Hoy, A. (2000). Collective teacher efficacy: Its meaning, measure, and impact on student achievement. American Education Research Journal, 37(2), 479-507.

Griffeth, R. W., Hom, P. W. ve Gaertner, S. (2000). A meta analysis of antecedents and correlates of employee turnover: Update, moderator tests and research 
implications for the next millennium. Journal of Management, 26(3), 463-488.

Hefferon, K. ve Boniwell, I. (2011). Positive psychology: theory, research and applications. New York: Mc Graw-Hill Open International Publishing Ltd.

Karakuş, M., Toprak, M. ve Gürpınar, M. (2014). Structural equation modelling on the relationships between teacher's trust in manager, commitment to manager, satisfaction with manager and intent to leave, Croatian Journal of Education, 16(1), 165-189.

Karasar, N. (2012). Bilimsel araştırma yöntemi. Ankara: Nobel Yayınlar1.

Kreitner, R. ve Kinichi, A. (2009). Organizational behaviour (Ninth edition). New York: Mc Graw-Hill International Edition.

Kurt, T. (2012). Öğretmenlerin öz yeterlik ve kolektif yeterlik algıları. Türk Eğitim Bilimleri Dergisi, 10(2), 195-227.

Kurz, T. B. ve Knight, S. L. (2004). An exploration of the relationship among teacher efficacy, collective teacher efficacy, and goal consensus. Learning Environments Research, 7(2), 111-128.

Luszczynska, A., Scholz, U., \& Schwarzer, R. (2005). The general self-efficacy scale: Multicultural validation studies. The journal of Psychology, 139(5), 439-457.

McEwan, E. K. (2018). Etkili okul yöneticilerinin 10 özelliği: İyi performanstan muhteşem performansa. N. Cemaloğlu(Çev. ed.). Ankara: Pegem Akademi Yayıncilik.

Öcal, H. ve Aydın, O. (2009). Spor takımlarında kolektif yeterlik, öz-yeterlik ve sargınlık algıları ile başarı algı ve beklentileri arasındaki ilişkiler. Hacettepe Üniversitesi Edebiyat Fakültesi Dergisi, 26(2), 155-174.

Özdemir, S. (2013). Eğitimde örgütsel yenileşme. Ankara: Pegem Akademi Yayıncılık.

Özkalp, E. ve Kırel, Ç. (2010). Örgütsel davranış. Bursa: Ekin Basım Dağıtım.

Robbins, S. P., Decenzo, D. ve Coulter, M. (2013). Yönetimin esasları. A. Öğüt(çev. ed.). Ankara: Nobel Akademik Yayıncılık.

Schunk, D. H. ve Pajares, F. (2005). Competence perceptions and academic functioning. In A. J. Elliott, \& C. S. Dweck (eds.), Handbook and competence and motivation (pp. 85-104). New York: Guilford Press.

Skaalvik, E. M. ve Skaalvik, S. (2010). Teacher selfefficacy and teacher burnout: A study of relations. Teaching and Teacher Education, 26, 1059-1069.

Şimşek, M.Ş., Çelik, A. ve Akgemci, T. (2014). Davranış bilimleri. Konya: Eğitim Yayınevi.

Tasa, K., Taggar, S. ve Seijts, G. H. (2007). The development of collective efficacy in teams: A multilevel and longitudinal perspective. Journal of Applied Psychology, 92, 17-27.

Tschannen-Moran, M. ve Barr, M. (2004). Fostering student learning: The relationship of collective teacher efficacy and student achievement. Leadership and Policy in Schools, 3(3), 189-209.

Templar, R. (2011). The rules of management (Expanded edition). New Jersey: Pearson Education Limited.

Yeni, Z. ve Özler, N. D. E. (2015). Duygusal emek.İçinde:N. D. E. Özler (Ed.), Örgütsel davranışta güncel konular (s. 329-362). Bursa: Ekin Yayınevi. 

